NSF urged to take multidisciplinary tack on environment

\section{Tony Reichhardt, Washington}

The National Science Foundation (NSF)

should build up environmental research in the United States by backing more multidisciplinary work and putting more resources into infrastructure and the training of young scientists, says an advisory committee.

The panel's 10-year-plan for environmental science at the NSF echoes earlier reports from both the National Academy of Sciences and the National Science Board (NSB) that governs the foundation. But the committee, which was chaired by Stephanie Pfirman, an environmental scientist at Barnard College in New York, failed to endorse a call by the NSB for a billion-dollar increase in annual environmental research spending by the NSF.

In 1999, the science board recommended tripling the NSF's $\$ 600$ million environmental research budget within five years. But since then, the programme has expanded only gradually, to $\$ 829$ million last year.

An academy report in 2000 identified eight "grand challenges" for environmental science, from understanding biodiversity to improving hydrologic forecasting. The advisory panel review, explains Margaret Leinen, an oceanographer who heads the NSF's geosciences directorate and coordinates its environmental research, was commissioned to recommend what part of that portfolio the NSF should take on between now and 2012 .

The review says that the NSF should focus on three areas: coupled human and natural systems, coupled biological and physical systems, and people and technology. Leinen says that the breadth of these categories reflects the need for a multidisciplinary approach — and that the NSF's support for environmental research will cut sharply across the agency's traditional, discipline-based organization. Study of the environmental impact of urban development, for example, may well involve both the geosciences and the social and behavioural sciences directorates.

Such collaboration is feasible in the short term in some areas, such as building computer systems to mine environmental data, Leinen says. But other areas, she adds, including the interaction of environmental and social sciences, may take longer to develop.

\title{
Biologists seek blueprint for international stem-cell effort
}

Erika Check, Washington

Scientists and policy-makers from around the world were this week set to lay the foundations of an international collaboration in human stem-cell research.

Representatives from the United States, Canada, Australia, Singapore, Finland, Sweden and Israel were due to meet in London as Nature went to press at the invitation of George Radda, chief executive of Britain's Medical Research Council, to discuss ways to hasten the development of any therapies that might result from stem-cell research.

Supporters say that what they term a 'human stem-cell project' would help to ensure that scientists from countries where such research is restricted could still contribute to this emerging field of biology.

Rules for research using human embryonic stem cells vary around the world. In particular, there are divergent approaches to the derivation of new stem cell lines - a procedure that is politically controversial as it involves the use of human embryos for research purposes.

In the United States, researchers are not allowed to use federal funds to derive and study new stem-cell lines, and in Germany, the derivation of new lines is forbidden by law. Meanwhile, scientists in the United Kingdom, Israel and Singapore can create and work on new stem-cell lines.

Roger Pedersen, a developmental biologist who in 2001 left the University of California, San Francisco, for the University of Cambridge, UK, says that he expects the international consortium to help researchers to contribute to stem-cell research while abiding with this patchwork of laws.

"It would be realistic to expect that novel

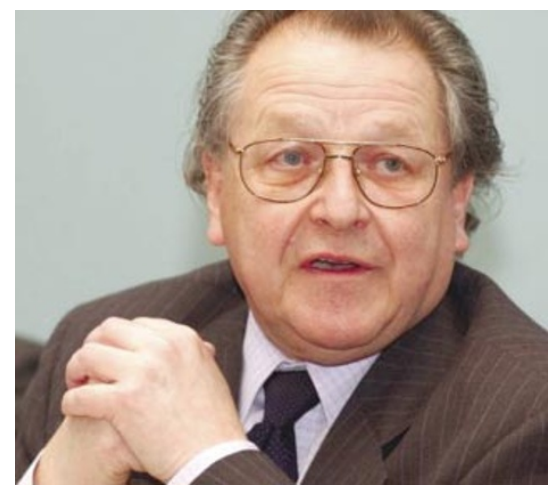

George Radda: convening experts in London.

embryonic stem-cell lines would be derived in the United Kingdom, Sweden and Singapore, and that US efforts would tend to focus on understanding how to control the in vitro differentiation of existing human embryonic stem-cell lines," Pedersen says. He adds that the international consortium is expected to lay out its goals in a series of meetings during the first half of this year.

An international stem-cell consortium could prove politically sensitive, and Radda's staff said that he couldn't comment on the planned meeting. But policy-makers initially seemed to welcome the idea.

For example, James Battey, head of the stem-cell task force at the US National Institutes of Health $(\mathrm{NIH})$, says that a central coordinating body could do much to advance stem-cell research around the world. He was planning to attend this week's meeting on behalf of the NIH. "By exploiting the strengths of what's possible in each country, maybe we'll be better able to move the science forward," Battey says.

\section{Comet mission hangs in the balance}

David Adam, London and Declan Butler, Paris

The European Space Agency's Rosetta mission faces an uncertain future this week after an agency inquiry failed to give it clearance for take off.

Rosetta, a US\$700-million plan to land a probe on the comet Wirtanen, was originally scheduled to launch on 12 January. But it was postponed after the failure of the Ariane 5 ECA 'heavy lifter' on its maiden flight last month (see Nature 420, 723; 2001).

An inquiry into whether the accident has any bearing on the classic Ariane 5 design, which will be used to take Rosetta on the first leg of its journey, reported on 7 January but failed to give the mission a green light. Rosetta has a very narrow launch window and must blast off by 31 January if it is to meet the comet.

At a press conference in Paris, Jean-Yves Le Gall, chief executive of Arianespace, which operates the Ariane rockets, said that the accident was caused by a cooling fault on the new engine, which suggests that the older Ariane 5 model is not at risk. But there are still doubts over whether the fault will affect Ariane 5 under the unusual conditions of the Rosetta launch, which requires the rocket to enter an Earth orbit and then re-fire. A separate investigation is now checking this, and will report on 14 January. 